\title{
Silicon mitigates heavy metal stress by regulating P-type heavy metal ATPases, Oryza sativa low silicon genes, and endogenous phytohormones
}

Yoon-Ha Kim ${ }^{1 \dagger}$, Abdul Latif Khan ${ }^{2 \dagger}$, Duk-Hwan Kim', Seung-Yeol Lee ${ }^{1}$, Kyung-Min Kim¹, Muhammad Waqas ${ }^{1}$, Hee-Young Jung ${ }^{1}$, Jae-Ho Shin', Jong-Guk Kim³ and In-Jung Lee ${ }^{1 *}$

\begin{abstract}
Background: Silicon (Si) application has been known to enhance the tolerance of plants against abiotic stresses. However, the protective mechanism of Si under heavy metals contamination is poorly understood. The aim of this study was to assess the role of Si in counteracting toxicity due to cadmium (Cd) and copper (Cu) in rice plants (Oryza sativa).

Results: Si significantly improved the growth and biomass of rice plants and reduced the toxic effects of $\mathrm{Cd} / \mathrm{Cu}$ after different stress periods. Si treatment ameliorated root function and structure compared with non-treated rice plants, which suffered severe root damage. In the presence of $\mathrm{Si}$, the $\mathrm{Cd} / \mathrm{Cu}$ concentration was significantly lower in rice plants, and there was also a reduction in lipid peroxidation and fatty acid desaturation in plant tissues. The reduced uptake of metals in the roots modulated the signaling of phytohormones involved in responses to stress and host defense, such as abscisic acid, jasmonic acid, and salicylic acid. Furthermore, the low concentration of metals significantly down regulated the mRNA expression of enzymes encoding heavy metal transporters (OsHMA2 and OsHMA3) in Si-metal-treated rice plants. Genes responsible for Si transport (OsLSi1 and OsLSi2), showed a significant up-regulation of mRNA expression with Si treatment in rice plants.
\end{abstract}

Conclusion: The present study supports the active role of $\mathrm{Si}$ in the regulation of stresses from heavy metal exposure through changes in root morphology.

Keywords: Silicon, Heavy metal stress, Root physiology, Phytohormones, P-type heavy metal ATPase, Oryza sativa, Low silicon

\section{Background}

Exposure to heavy metal toxicity has become a major limiting factor in the growth and yield of crop plants, affecting the sustainability of agricultural production and hence threatening food security. Heavy metal toxicity retards plant growth by marginalizing the cellular functions of proteins, lipids, and elemental components of thylakoid membranes. Disturbances in the thylakoid membranes, organelles indispensable for photosynthetic activity, are often correlated with senescence processes [1-3]. Among heavy metals, cadmium (Cd) and copper $(\mathrm{Cu})$ have been known to hinder the growth of crop

\footnotetext{
* Correspondence: ijlee@knu.ac.kr

${ }^{\dagger}$ Equal contributors

'School of Applied Biosciences, College of Agriculture and Life Science,

Kyungpook National University, Daegu 702-701, Republic of Korea

Full list of author information is available at the end of the article
}

plants, especially rice plants. Rice paddies are contaminated by $\mathrm{Cd} / \mathrm{Cu}$ in phosphate fertilizers, sludge, and irrigated water. $\mathrm{Cd}$ absorbed and transported inside rice plants can create severe health problems because rice is consumed on a daily basis [4-7]. Cu bioaccumulation inside plant tissues tends to disturb the enzymatic activities required for chlorophyll biosynthesis [2]. In addition, $\mathrm{Cd} /$ $\mathrm{Cu}$ influences leaf elongation, cell wall elasticity, potassium levels, and sugar accumulation [8].

Cadmium $(\mathrm{Cd})$ and copper $(\mathrm{Cu})$ are taken together with other elements (such as $\mathrm{K}, \mathrm{Ca}, \mathrm{Mg}$, and $\mathrm{Fe}$ ), through the transmembrane carrier from the root cortex to the stele $[9,10]$. The uptake of heavy metals is influenced by metaltransporting transmembrane proteins, including Heavy Metal ATPases (HMAs), Low-affinity Cation Transporters (LCTs) and Iron-regulated Transporters (IRTs) $[7,11,12]$. 
These commonly known metal transport genes are located throughout the structure of plant which translocate a diverse set of metal ions [13,14]. Previous studies in Arabidopsis thaliana have confirmed the physiological functions of the HMAs (AtHMA1, AtHMA2, AtHMA3, and AtHMA4) that is to detoxify zinc from chloroplast and signal $\mathrm{Cd}$ accumulation in the vacuoles and plasma membrane [15-18].

$\mathrm{Cd} / \mathrm{Cu}$ causes the formation of reactive oxygen species (ROS) [10] that damage membrane permeability and function. Peroxides of polyunsaturated fatty acids generate malondialdehyde (MDA), the most abundant aldehydic lipid breakdown product [19] that indicates the levels of stress and injury to the functional membrane. To counteract these of stress conditions, plant hormones also play a central role. For example, jasmonic acid (JA) and salicylic acid (SA) are involved in defense-related signaling during stress conditions. In addition, abscisic acid (ABA), a stress-responsive hormone, is involved with stomatal closure to ensure plants do not lose a substantial amount of water [20].

To mitigate and reduce the negative effects of heavy metals, various prospects have been evaluated. Silicon (Si) has been found to serve as a beneficial element for plant growth and development [21]. It is the second most abundant element in soil and readily absorbed; terrestrial plants contain it at an appreciable concentration, $1 \%$ to $10 \%$ or even higher in plant dry matter [21]. Si is an essential component of rice plants and its accumulation is helpful in maintaining sustainable production [22]. The physiological functions of $\mathrm{Si}$ have been studied extensively and $\mathrm{Si}$ is known as an essential constituent of plants and fertilizers [21,23-26]. Numerous studies have revealed that $\mathrm{Si}$ is a beneficial element to higher plants, particularly grasses and various cultivated crops like rice, wheat, tomato, and cucumber [21,23,27-30]. Over the last decade, studies have revealed the ability of $\mathrm{Si}$ to mitigate various biotic (plant diseases and pests) and abiotic stresses (heavy metals, drought, and salinity) in crop plants [20]. Ma et al. [31] has reported that Si influx and efflux strongly regulate a set genes, Oryza Satica Low Silicon Rice 1 and 2 (OsLsi1 and OsLsi2), in the plasma membrane of rice plant cells. OsLsi1 is localized at the distal side of the cell while OsLsi2 is confined to the proximal side of the same cell and both are arranged on casparian strips [31]. The role of these two genes in Si transport and stress conditions is still unknown. To understand these interactions, the aim of this study was to assess the role of OsLsi1 and OsLsi2 during heavy metal $(\mathrm{Cd}$ and $\mathrm{Cu})$ exposure to rice plants under Si treatments. We also investigated the role of $H M A s$ during heavy metal toxicity and their regulation during the application of Si. In response to metal stress, the regulation of the phytohormones salicylic acid, abscisic acid, and jasmonic acid were also analyzed.

\section{Results}

Si improves rice plant growth under heavy metal exposure

The effect of $\mathrm{Si}$ and heavy metal $(\mathrm{Cu}$ and $\mathrm{Cd})$ treatments on rice plant growth was assessed after different time points (1, 5, and 10 days after treatment - DAT; Figure 1). The results showed that $\mathrm{Si}$ application significantly increased plant growth attributes as compared with the control plants (non-Si) under normal growth conditions. After 24 h exposure to heavy metal stress, $\mathrm{Cu}$ significantly affected the shoot and root lengths of rice plants as compared to $\mathrm{Cd}$. After 5 and 10 days of $\mathrm{Cu}$ or $\mathrm{Cd}$ treatments, the shoot growth was significantly reduced as compared with control and Si treatment (Figure 1).

Metal stress has significantly decreased the root length of rice plants as compared to control plants under normal growth conditions. Treatment with $\mathrm{Cd}$, in particular, significantly affected the root architecture and reduced the root length as compared with plants treated with $\mathrm{Cu}$, $\mathrm{Cu}+\mathrm{Si}$ or $\mathrm{Cd}+\mathrm{Si}$ after 1,5 , and 10 DAT. In case of chlorophyll content, after one day, $\mathrm{Si}$ and $\mathrm{Si}+\mathrm{Cu}$ had no significant difference as compared to control, but these treatments had higher chlorophyll than $\mathrm{Cd}, \mathrm{Cu}$, and $\mathrm{Cd}+\mathrm{Si}$ treatments. After 5 and 10 days of treatment, the chlorophyll content was significantly higher in Si-treated plants as compared to metal stressed plants (Figure 1).

The heavy metals treatment has adversely affected the biomass (shoots and roots) and phenotypic characters of rice plants. Although, there was no significant effect on the biomass or phenotypic characteristics after $\mathrm{Si}$ and non-Si treated metal stress after day 1 (Figure 1). However, we observed a significant difference after 5 and 10 days of metal stress in Si-treated plants, where a significantly higher biomass (in fresh weight) of shoots and roots was observed. The biomass of the shoots and roots was also significantly different with $\mathrm{Si}$ treatment as compared to non-metal-treated control plants. In terms of phenotypic characteristics, leaf damage and necrosis were pronounced with $\mathrm{Cd}$ treatment (compared with $\mathrm{Cu}$ treatment) after 5 and 10 DAT. Phenotypic characteristics were also significantly ameliorated with Si application after 5 and 10-DAT because $\mathrm{Si}$ treatment with metal stress showed relatively lower rates of necrosis and leaf damage.

Si affects heavy metal transport in the roots of rice plants $\mathrm{Cd} / \mathrm{Cu}$ ions concentration was measured in the rice roots after the application of metal stress and $\mathrm{Si}$. $\mathrm{Cd}$ concentration was undetected in the control, $\mathrm{Si}$ and $\mathrm{Cu}$ treatments after 1, 5, or 10 days. However, Cd accumulation in rice plants with Cd-treatment was significantly higher than $\mathrm{Si}+\mathrm{Cd}$ at 1, 5, and 10-DAT (Table 1). The $\mathrm{Cd}$ concentration was approximately $2.3,2.4$ and 1.9 fold 

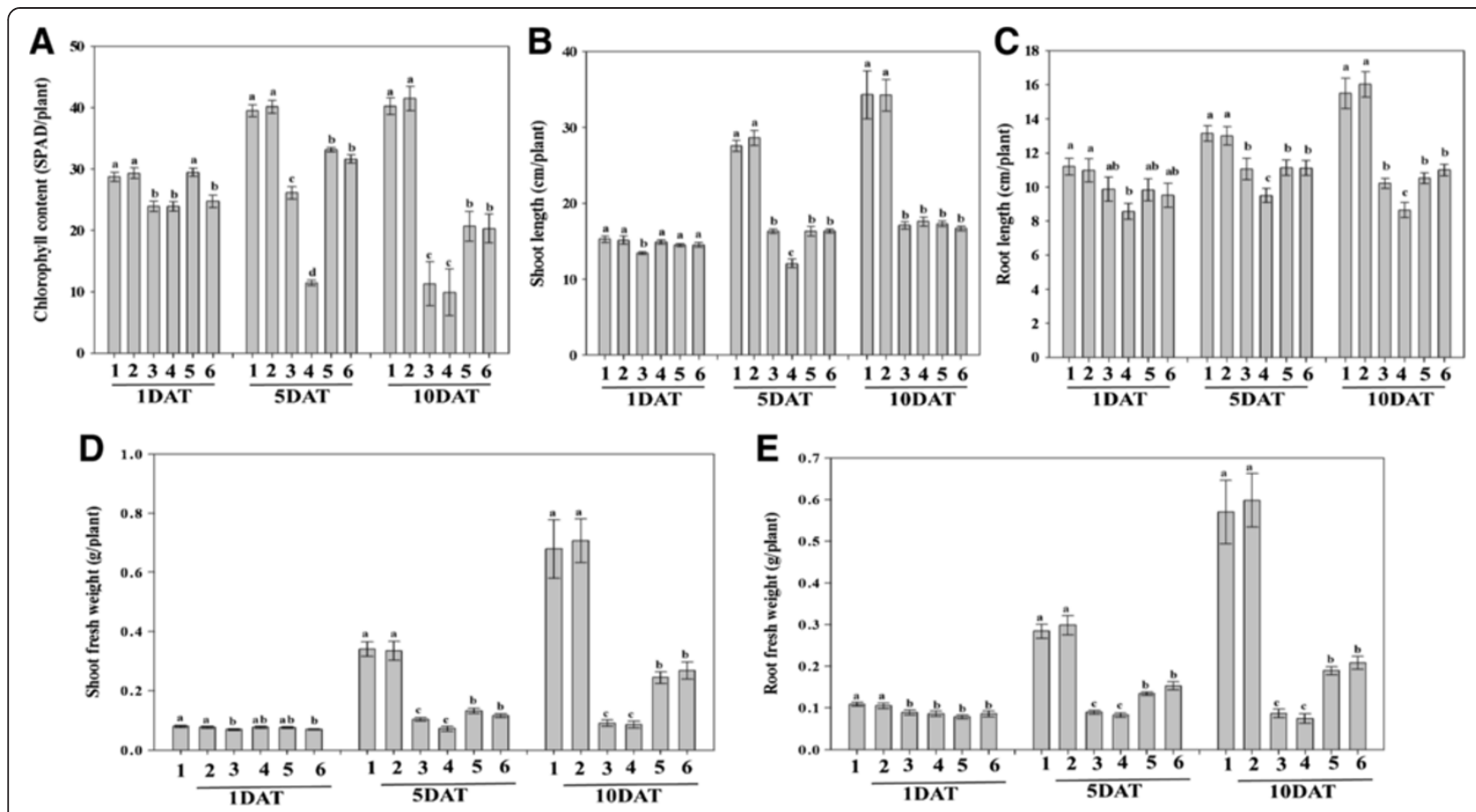

Figure 1 Effects of heavy metal $(\mathrm{Cu} / \mathrm{Cd})$ with and without $\mathrm{Si}(1.0 \mathrm{mM})$ application on physiological parameters of rice plants. Surveys of all the physiological parameters were recorded after 1,5 and 10 days treatments (DAT). In the figure, number indicated different treatments (1-Control; 2-Si; 3- Cu; 4- Cd; 5- Cu + Si; 6- Cd + Si). A - chlorophyll contents; B - Shoot length; C - Root length; D - Shoot fresh weight; E - Root fresh weight of the rice plants. Bars represent means of 81 plants that is the sum of three replications per treatment \pm standard error. Means denoted by the same letter were not significantly different at $P>0.05$ by Duncan Multiple Range Test (DMRT).

higher in the Cd-treated rice compared to $\mathrm{Si}+\mathrm{Cd}$ at 1 , 5, and 10-DAT, respectively.

The $\mathrm{Cu}$ concentration was not significantly different in the control, $\mathrm{Cd}$, and $\mathrm{Si}+\mathrm{Cd}$ treated plants at 1,5 , and 10-DAT. On the other hand, $\mathrm{Cu}$ accumulation was significantly higher in the $\mathrm{Cu}$-treated plants as compared with the $\mathrm{Si}+\mathrm{Cu}$ plants after 1, 5, and 10-DAT. The $\mathrm{Cu}$ accumulation was approximately 2.0, 1.2 and 1.7 fold higher in $\mathrm{Cu}$-treated plants compared with the $\mathrm{Si}+\mathrm{Cu}$ at 1,5 , and 10-DAT, respectively.

$\mathrm{Si}$ accumulation in rice roots was significantly different in $\mathrm{Cd}$ and $\mathrm{Cu}$-treated rice plants compared to the control after 1, 5 and 10-DAT. However, the level of Si accumulation was significantly higher in plants treated with $\mathrm{Si}+\mathrm{Cu}$, or $\mathrm{Si}+\mathrm{Cd}$ after 1,5, and 10 DAT. Overall, the $\mathrm{Si}+\mathrm{Cu}$ treatment accumulated $\mathrm{Si}$ in higher quantities in the roots compared to the $\mathrm{Si}+\mathrm{Cd}$ rice plants after 1, 5, and 10-DAT (Table 1).

Si improves root morphology during metal stress treatment To assess the effects of metal stress and Si treatment on root morphology and structure, sections $(2 \mathrm{~cm})$ from the rice roots were obtained from each sample at 1,5 , and 10-DAT. Light microscopic analysis showed that the exodermis (EX), epidermis (EP), endodermis (EN) and cortex regions of the plants treated with $\mathrm{Cd}$ or $\mathrm{Cu}$ were slightly affected as compared to Si-treated control roots at 1-DAT (Figure 2). The cellular spaces were wider in the non-Si-treated plant roots and the suberin lamellae were partially broken at instant places (arrow). In contrast, the suberin lamellae of the EX, EP, and cortex regions in the $\mathrm{Si}$ and metal-treated plants $\mathrm{Cu}+\mathrm{Si}$ and $\mathrm{Cd}+\mathrm{Si}$ ) were fully developed and lacked any visible deformities. In the cortex regions, the damage was more vigorous in $\mathrm{Cu}$ and $\mathrm{Cu}+\mathrm{Si}$ compared with $\mathrm{Cd}$ and $\mathrm{Cd}+\mathrm{Si}$ at 1-DAT (Figure 2).

The deleterious effects of $\mathrm{Cd}$ and $\mathrm{Cu}$ were more severe after 5 and 10-DAT. Although the stele and epidermal suberin lamellae were still intact, the EN and cortex regions were severely damaged and poorly differentiated. The root cellular apparatus was severely broken and damaged at 10-DAT after exposure to $\mathrm{Cd}$ and $\mathrm{Cu}$ stress. The $\mathrm{Cu}$-treated roots, compared to $\mathrm{Cd}$, were more deformed in shape and size; moreover, the $\mathrm{Cu}$-treated tissue parts were poorly differentiated. In case of $\mathrm{Si}$ and metal treatment, endodermal suberin lamellae were closer to each other, while fewer walls were damaged in the $\mathrm{Cd}+\mathrm{Si}$ plants compared to plants treated with $\mathrm{Cd}$ and $\mathrm{Cu}$ alone (Figure 2). In $\mathrm{Cu}+\mathrm{Si}$ and $\mathrm{Cd}+\mathrm{Si}$ treatments, the negative effects of metal stress were substantially less, although the cortex cellular lamellae were broken at various places. These effects were more pronounced in $\mathrm{Cu}+\mathrm{Si}$ compared with $\mathrm{Cd}+\mathrm{Si}$ treatments. 
Table 1 lon concentrations of $\mathrm{Cd}, \mathrm{Cu}$ and $\mathrm{Si}$ in the rice root under stress

\begin{tabular}{|c|c|c|c|}
\hline \multirow[t]{2}{*}{ Treatments } & \multicolumn{3}{|c|}{ Ion concentrations $\left(\mu \mathrm{mol} \mathrm{g} \mathrm{g}^{-1}\right)$} \\
\hline & Cd & $\mathrm{Cu}$ & $\mathrm{Si}$ \\
\hline \multicolumn{4}{|c|}{ 1-DAT } \\
\hline Control & ND & $20.8 \pm 2.1 c$ & $201.32 \pm 3.21 d$ \\
\hline $\mathrm{Si}$ & ND & $37.8 \pm 4.6 c$ & $765.8 \pm 39.8 c$ \\
\hline $\mathrm{Cu}$ & ND & $2777.4 \pm 207.1 \mathrm{a}$ & $677.6 \pm 22.7 c$ \\
\hline $\mathrm{Cd}$ & $611.5 \pm 78.0 \mathrm{a}$ & $39.2 \pm 2.1 c$ & $788.1 \pm 58.4 c$ \\
\hline $\mathrm{Cu}+\mathrm{Si}$ & ND & $1374.0 \pm 179.6 b$ & $3482.6 \pm 155.9 \mathrm{a}$ \\
\hline $\mathrm{Cd}+\mathrm{Si}$ & $263.2 \pm 14.2 \mathrm{~b}$ & $28.0 \pm 3.6 c$ & $2104.2 \pm 17.3 b$ \\
\hline \multicolumn{4}{|c|}{ 5-DAT } \\
\hline Control & ND & $24.5 \pm 1.2 \mathrm{~d}$ & $234.2 \pm 5.2 \mathrm{~d}$ \\
\hline Si & ND & $45.0 \pm 4.9 \mathrm{C}$ & $600.5 \pm 8.9 c$ \\
\hline $\mathrm{Cu}$ & ND & $2398.3 \pm 88.0 \mathrm{a}$ & $612.8 \pm 65.7 c$ \\
\hline $\mathrm{Cd}$ & $934.0 \pm 49.4 \mathrm{a}$ & $45.6 \pm 4.7 c$ & $797.7 \pm 54.2 \mathrm{c}$ \\
\hline $\mathrm{Cu}+\mathrm{Si}$ & ND & $1903.4 \pm 14.8 b$ & $1778.8 \pm 35.4 \mathrm{a}$ \\
\hline $\mathrm{Cd}+\mathrm{Si}$ & $399.6 \pm 15.7 b$ & $37.7 \pm 4.1 \mathrm{C}$ & $1383.7 \pm 49.8 b$ \\
\hline \multicolumn{4}{|c|}{ 10-DAT } \\
\hline Control & ND & $31.3 \pm 6.1 \mathrm{~d}$ & $119.2 \pm 2.4 \mathrm{~d}$ \\
\hline Si & ND & $48.8 \pm 6.9 c$ & $126.1 \pm 9.0 \mathrm{~d}$ \\
\hline $\mathrm{Cu}$ & ND & $1433.8 \pm 105.2 \mathrm{a}$ & $167.1 \pm 14.3 \mathrm{C}$ \\
\hline $\mathrm{Cd}$ & $680.7 \pm 30.9 \mathrm{a}$ & $51.0 \pm 2.3 c$ & $170.6 \pm 45.0 \mathrm{c}$ \\
\hline $\mathrm{Cu}+\mathrm{Si}$ & ND & $977.8 \pm 16.8 b$ & $390.9 \pm 19.4 \mathrm{a}$ \\
\hline $\mathrm{Cd}+\mathrm{Si}$ & $342.0 \pm 42.9 b$ & $49.5 \pm 0.6 c$ & $231.1 \pm 61.7 b$ \\
\hline
\end{tabular}

Mean \pm standard error from three replications per treatment. ND, Not detected; DAT, Days after treatment. In the column, the same letters indicate not significant difference $(P>0.05)$ by Duncan's Multiple Range Test (DMRT).

After 10-DAT, the adverse effects were further evident in the $\mathrm{Cu}+\mathrm{Si}$ plants than in the $\mathrm{Cd}+\mathrm{Si}$ plants. Altogether, this indicates that $\mathrm{Si}$ application has an ameliorative role in the $\mathrm{Cd}$ stress regulation (compared to $\mathrm{Cu}$ ) in root morphology of rice plants.

\section{Si regulates phytohormones during heavy metal stress}

Plant hormones were regulated during the stress conditions with or without the application of silicon. Upon $\mathrm{Cd} / \mathrm{Cu}$ treatments, the endogenous abscisic acid (ABA) content was significantly increased in 1 and 5-DAT. $\mathrm{ABA}$ was initially higher with $\mathrm{Cu}$ treatments as compared to Cd; however, the opposite was observed at 5-DAT. Although the ABA levels were still higher compared with the Si-treated control plants at 5-DAT, the application of Si significantly lowered the ABA levels under metal stress. At 10-DAT, the $\mathrm{Cu}$ or $\mathrm{Cd}$ treatment had slightly higher ABA levels compared to the control (Figure 3). In Si treatment, the ABA content was significantly up-regulated with $\mathrm{Si}+\mathrm{Cd} /$ $\mathrm{Cu}$ treatments compared to the control at 1 and 5-DAT and also with the sole $\mathrm{Cd} / \mathrm{Cu}$ treatment at 10-DAT. The results suggest that $\mathrm{Si}$ initially counteracted the responses to heavy metal stress; however, with increasing stress periods, the stress-responsive ABA was exponentially activated.

The response pattern of endogenous jasmonic acid (JA) was different from ABA. In a previous study [30], Si application to rice plants reduced JA biosynthesis under wounding stresses. In this study, heavy metal stress caused a similar JA response. The JA content was significantly higher with sole $\mathrm{Cd}$ stress compared with $\mathrm{Cu}$ stress. In $\mathrm{Si}$ treatment, comparing the $\mathrm{Si}$ and $\mathrm{Si}+\mathrm{Cd} / \mathrm{Cu}$ treatment, the JA content from $\mathrm{Cd} / \mathrm{Cu}$ treatments was significantly up-regulated. The JA level was not significantly different between the $\mathrm{Si}+\mathrm{Cd}$ and $\mathrm{Si}+\mathrm{Cu}$ treatments and the different stress periods did not affect the JA content during $\mathrm{Si}$ application. Our results suggest $\mathrm{Si}$ application reduces JA biosynthesis under heavy metal stress (Figure 3).

Silicon application increased the synthesis of salicylic acid (SA) depending on the duration of the $\mathrm{Cd} / \mathrm{Cu}$ stress (Figure 3). The effect of SA biosynthesis was not significantly different between the $\mathrm{Cd}$ and $\mathrm{Cu}$ treatment alone at 1, 5, and 10-DAT. The SA content was $2 \sim 3$ fold higher with $\mathrm{Cu}$ or $\mathrm{Cd}$ treatments than in the control, $\mathrm{Si}, \mathrm{Si}+\mathrm{Cu}$, or $\mathrm{Si}+\mathrm{Cd}$ treatments (Figure 3). Si application and metal stress had no significant effect on the SA quantities at 1-DAT, but at 5-DAT and 10-DAT, the SA content was significantly higher in $\mathrm{Cd}$ compared to $\mathrm{Cu}$ (Figure 3 ).

The results of our phytohormonal analyses showed that the content of ABA, SA and JA exponentially increase with $\mathrm{Cd} / \mathrm{Cu}$ stress compared to $\mathrm{Si}$ treatments. Similarly, periodic exposure initially increased phytohormonal responses with $\mathrm{Cd} / \mathrm{Cu}$ treatment compared to the $\mathrm{Si}$ treatments. We also observed cross-talk in the hormonal responses to $\mathrm{Cd} / \mathrm{Cu}$.

\section{Si decreases lipid peroxidation activity and affects fatty acid composition under heavy metal stress}

The level of lipid peroxidation was measured from the malondialdehyde (MDA) content (Figure 4). Lipid peroxidation was significantly higher with the $\mathrm{Cd} / \mathrm{Cu}$ treatments at 1 and 5-DAT compared to $\mathrm{Si}+\mathrm{Cd} / \mathrm{Cu}$. The MDA level in plants with $\mathrm{Si}$ and metal stress after 1DAT was not significantly different from the control; however, at 5 and 10-DAT, the MDA levels were significantly higher compared to control. The analyses also showed low level of lipid membrane degradation with $\mathrm{Si}$ application compared to non-Si plants under metal stress (Figure 4).

To further analyze the lipid membrane damage, three fatty acids (palmitic acid (C 16:0), linoleic acid (C 18:2) and linolenic acid (C 18:3) were quantified in rice plants treated with metals and Si (Figure 4). The percentages of fatty acids at 1-DAT were not significantly different for all the treatments. At 5 and 10-DAT, however, the percentage of $\mathrm{C} 18: 3$ was significantly reduced with the $\mathrm{Cd} /$ 


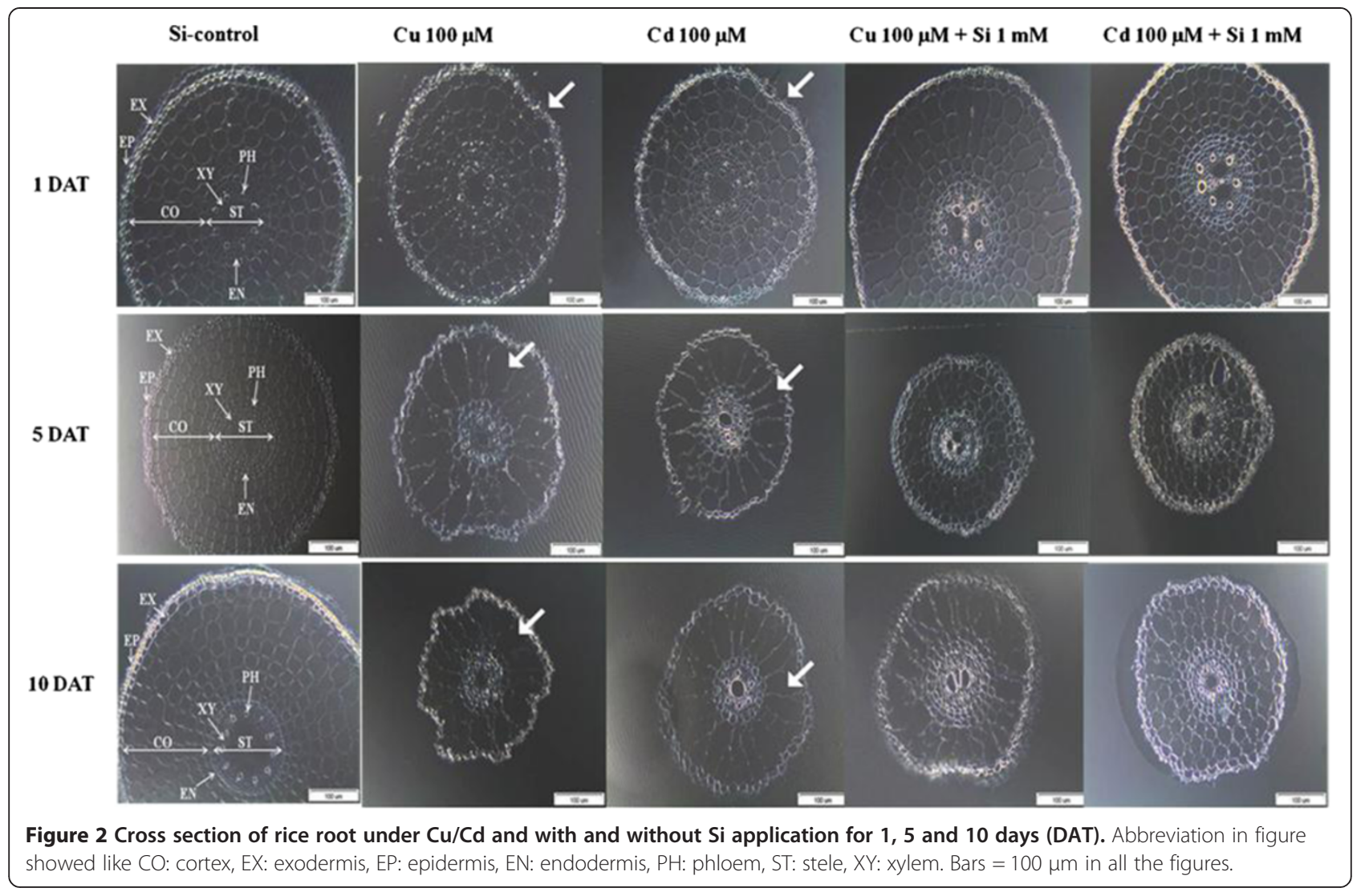

$\mathrm{Cu}$ treatment compared to the control, and $\mathrm{Cd} / \mathrm{Cu}$ with Si treatments had higher levels of $\mathrm{C}$ 18:3 compared to the $\mathrm{Cd} / \mathrm{Cu}$ treatments alone (Figure 4). C 16:0 and C 18:2 showed the opposite trend; at 1-DAT, there were no significant differences between the treatments, but at 5 and 10-DAT, these fatty acids were significantly higher in the $\mathrm{Cd} / \mathrm{Cu}$-treatment compared to the $\mathrm{Si}+\mathrm{Cd} /$ $\mathrm{Cu}$-treatments (Figure 4).

\section{Si inhibits expressions of OsHMA2 and OsHMA3 under heavy metal stress}

According to previous reports of Hussain et al. [32], Andrés-Colás et al. [33], Courbot et al. [16], Lee et al. [14], Nocito et al. [34], and Satoh-Nagasawa et al. [12], heavy metal ATPases (encoded by the HMA genes) are key regulators of the heavy metal stress responses and transport in most of the higher plants. We assessed the expressions of HMA genes (OsHMA2 and OsHMA3) in rice plants. The mRNA expressions of OsHMA2 and OsHMA3 were analyzed in $\mathrm{Si}$, non-Si and $\mathrm{Cd} / \mathrm{Cu}$ treatments (Figure 5). The relative expression of OsHMA2 at 1-DAT was significantly higher with $\mathrm{Cd} / \mathrm{Cu}$ treatments compared to Si-treatments. OsHMA2 was also higher with the $\mathrm{Cd} / \mathrm{Cu}+\mathrm{Si}$ treatments compared with sole $\mathrm{Si}$ and control but was significantly lower than the $\mathrm{Cd} / \mathrm{Cu}$ treatments without $\mathrm{Si}$. A similar tendency was observed at 5-DAT; however, at 10-DAT, OsHMA2 was not exponentially expressed compared with the other treatments. The mRNA expression of OsHMA3 was similar at 1 and 5-DAT, but after 10-DAT, it was significantly increased in the non-Si $\mathrm{Cu}$ rice plants compared with $\mathrm{Si}+\mathrm{Cd} / \mathrm{Cu}$ and Cd-treated plants (Figure 5).

\section{Si increases the expression of OsLsi1 and OsLsi2 under heavy metal stress}

The Oryza sativa low silicon genes (OsLsi1 and OsLsi2) regulate $\mathrm{Si}$ influx and efflux in the roots of rice plants $[31,35]$. To assess the heavy metal stress-induced regulation of these two genes with $\mathrm{Si}$, we determined the mRNA expression level of OsLsi1 and OsLsi2 in rice plants (Figure 5). The expression level of OsLsi1 at 1DAT revealed no significant differences between the $\mathrm{Si}$ alone, control, and $\mathrm{Cd} / \mathrm{Cu}$ treatments; however, it was exponentially expressed in the $\mathrm{Si}+\mathrm{Cd} / \mathrm{Cu}$-treated plants (Figure 5). Similarly, the relative mRNA levels of OsLsi1 were significantly down-regulated with $\mathrm{Cd} / \mathrm{Cu}$ application at 5-DAT but highly up-regulated with $\mathrm{Si}$ and $\mathrm{Si}+$ $\mathrm{Cd} / \mathrm{Cu}$ application (Figure 5). At 10-DAT, the expression level of OsLsi1 was down-regulated with the $\mathrm{Cd} / \mathrm{Cu}$ treatments compared to the Si-treated plants. In the $\mathrm{Si}+$ $\mathrm{Cd} / \mathrm{Cu}$ treatments, OsLsi1 was also more expressed than with $\mathrm{Cd} / \mathrm{Cu}$ treatments alone (Figure 5). 


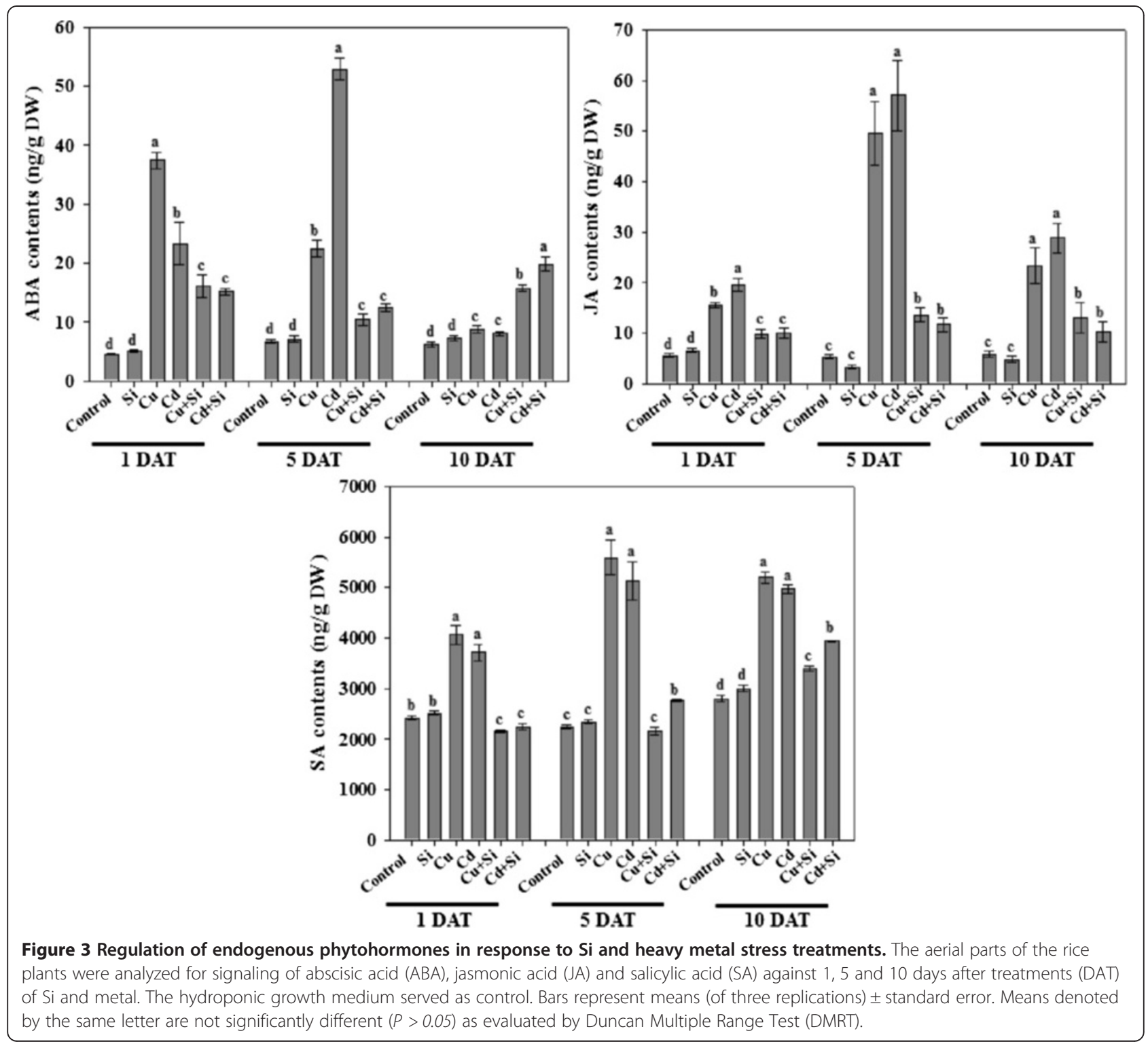

A similar expression pattern was observed for OsLSi2. The relative mRNA level of OsLsi2 at 1-DAT was upregulated with $\mathrm{Cd} / \mathrm{Cu}$ alone and $\mathrm{Si}+\mathrm{Cd} / \mathrm{Cu}$ treatment than in the Si-treated control. However, the expression of OsLsi2 was more highly expressed with $\mathrm{Si}+\mathrm{Cd} / \mathrm{Cu}$ treatment compared to the $\mathrm{Cd} / \mathrm{Cu}$ plants without $\mathrm{Si}$ (Figure 5). At 5-DAT, the relative mRNA level of OsLsi2 was significantly down-regulated with the $\mathrm{Cd} / \mathrm{Cu}$ treatments compared with the control, $\mathrm{Si}$ alone and $\mathrm{Si}+\mathrm{Cd} /$ $\mathrm{Cu}$-treated plants (Figure 5). At 10-DAT, the relative mRNA level of OsLsi2 was significantly down regulated in $\mathrm{Cd} / \mathrm{Cu}$ and $\mathrm{Cd} / \mathrm{Cu}+\mathrm{Si}$ than in the control and $\mathrm{Si}$ alone. Si application during $\mathrm{Cd} / \mathrm{Cu}$ stress significantly activated the OsLsi2 enzymes to counteract the negative effects of the heavy metals. Because there was no stress during the treatment with $\mathrm{Si}$ alone, OsLsi1 and OsLsi2 maintained their expression at 5 and 10-DAT.

\section{Discussion and conclusions}

Heavy metals released into the environment tend to accumulate in soils and become available to plants through their roots [36,37]. In rice paddy fields, the heavy metals $\mathrm{Cd}$ and $\mathrm{Cu}$ are readily absorbed into rice roots, which are transported to the shoot parts through the symplastic pathway [4-7,38-40]. An increased concentration of $\mathrm{Cd} / \mathrm{Cu}$ causes the inhibition of cellular processes such as photosynthesis, electron transport, and lipid peroxidation due to the binding of these metals to sulfhydryl groups [2,41,42].

We found that $\mathrm{Cd} / \mathrm{Cu}$ application significantly affects the growth of rice plants. The rice plants had a reduction 


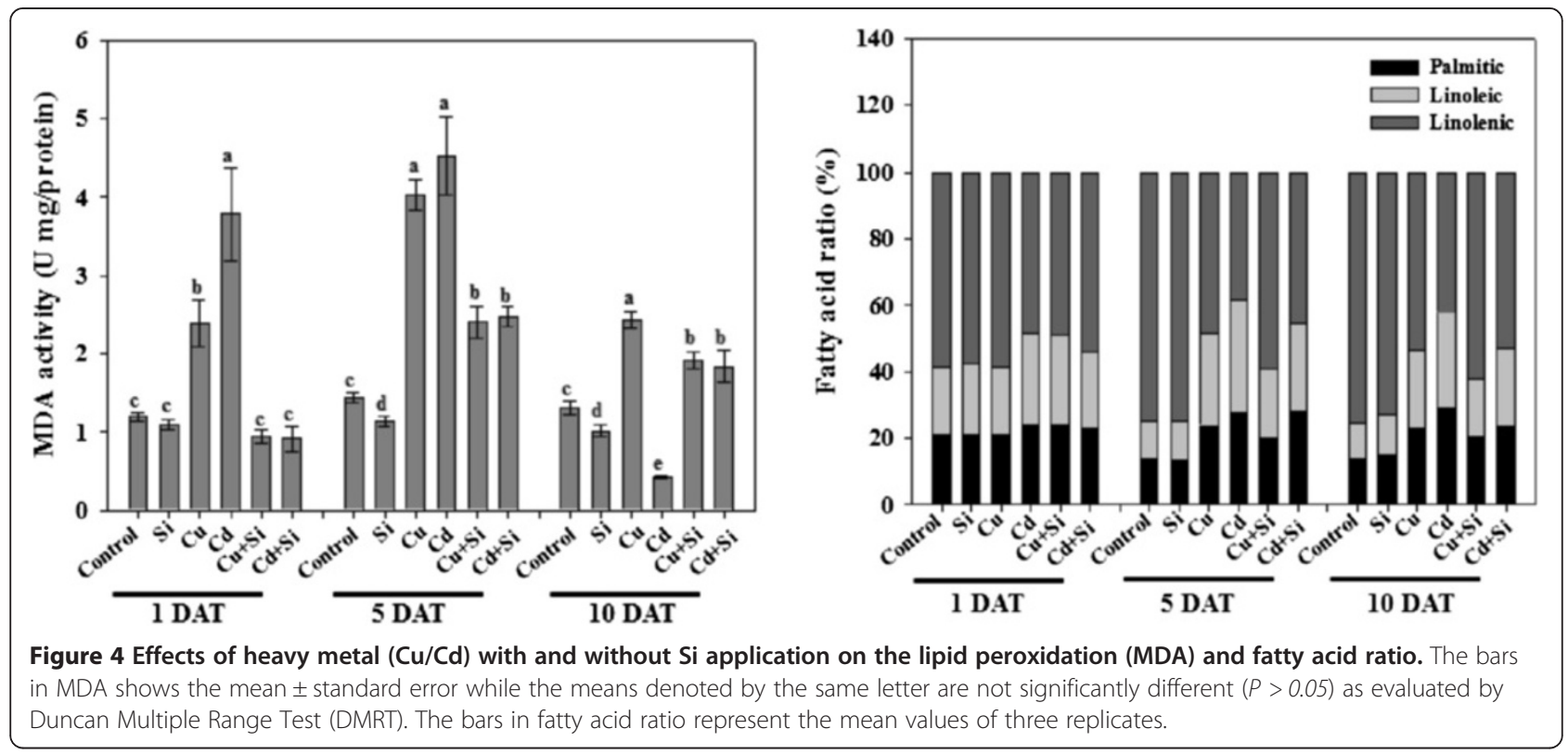

in chlorophyll content after exposure to $\mathrm{Cd} / \mathrm{Cu}$. Chlorophyll degradation further reduced the shoot length and biomass of the rice plants after different heavy metal stress periods. In addition, the rice plants had a lower root length and biomass after an exposure to $\mathrm{Cd} / \mathrm{Cu}$ stress. Langer et al. [43] and Liu et al. [44] previously found that heavy metals applied to rice plants caused a very weak root growth pattern and morphology while $\mathrm{Si}$ ameliorated this impact. In Brassica napus, Cd at a low concentration $(5 \mu \mathrm{M})$ reduced the plant growth, chlorophyll content, and photosynthesis, leading to stomatal closure [45]. We observed similar negative effects in the root structure of the $\mathrm{Cd} / \mathrm{Cu}$-treated rice plants. However, these adverse effects were greatly minimized with exogenous $\mathrm{Si}$-application. Various physiological parameters, such as shoot and root length, biomass, and chlorophyll content were significantly higher in the Si-treated plants compared to the control plants under heavy metal stress.

Our results further suggest that Si-treatment reduces the accumulation of heavy metals in rice roots. The accumulation of $\mathrm{Cd} / \mathrm{Cu}$ inside the root tissues of $\mathrm{Cd} /$ $\mathrm{Cu}$-treated plants was significantly higher compared with the $\mathrm{Si}+\mathrm{Cd} / \mathrm{Cu}$-treatments. The effects of $\mathrm{Si}$-application on the alleviation of $\mathrm{Cd}$ toxicity in our experiment were comparable to previous reports where $1.8 \mathrm{mM}$ of exogenous $\mathrm{Si}$ increased the fresh weight of rice seedlings grown in solutions contaminated with Cd [46]. The non-Si-treated plants, on the other hand, were significantly affected by the negative effects of metal stress, as revealed in our micrographs of the rice roots. The root cell structure of the epidermis, exodermis, and cortex were seriously damaged with increasing durations of $\mathrm{Cu}$ or $\mathrm{Cd}$ stress, while the root structure was less affected by $\mathrm{Si}$ treatment. In addition, $\mathrm{Cd} / \mathrm{Cu}$ accumulation was much more pronounced with $\mathrm{Cd} / \mathrm{Cu}$ treatment alone compared to the Si-treated plants. This likely reflects the binding of heavy metals in a stable complex with further distribution inside the root, an activity minimized with the Si treatments compared to the non-Si plants. The possible mechanisms for Si inhibition of metal transport in plants may be due to the thickening of the casparian strips in the endodermis and cell wall of the xylem causing the deposition of lignin and Si in the cell walls of the dermal regions $[47,48]$.

In addition, excessive $\mathrm{Cu}$ induces leaf chlorosis due to peroxidative breakdown of the pigments and lipid membrane [5]. We found that Si modulated both leaf chlorosis and lipid peroxidation in rice plants. Lipid peroxidation indicates oxidative stress damage on the membrane due to metal toxicity [49-51]. The results demonstrate that lipid peroxidation was significantly higher in the $\mathrm{Cd} / \mathrm{Cu}$ rice plants compared to the Si-control; however, MDA generation with $\mathrm{Si}+\mathrm{Cd} / \mathrm{Cu}$ treatments was significantly reduced. The degree of lipid peroxidation is usually measured by the concentration of secondary breakdown products derived from these initial hydroperoxides. Peroxides of polyunsaturated fatty acids generate malondialdehyde (MDA) on decomposition, and MDA is typically the most abundant individual aldehydic lipid breakdown product [52]. It has been estimated that more than $75 \%$ of the measured MDA is derived from $\alpha$-linoleic acid [53]. Metal stress significantly reduced the percentage of $\alpha$-linoleic acid, suggesting a higher attack from reactive oxygen species (ROS) at the lipid membrane compared to plants provided with $\mathrm{Si}$. We conclude that having high concentrations of $\alpha$-linolenic acid in chloroplasts and mitochondria, 


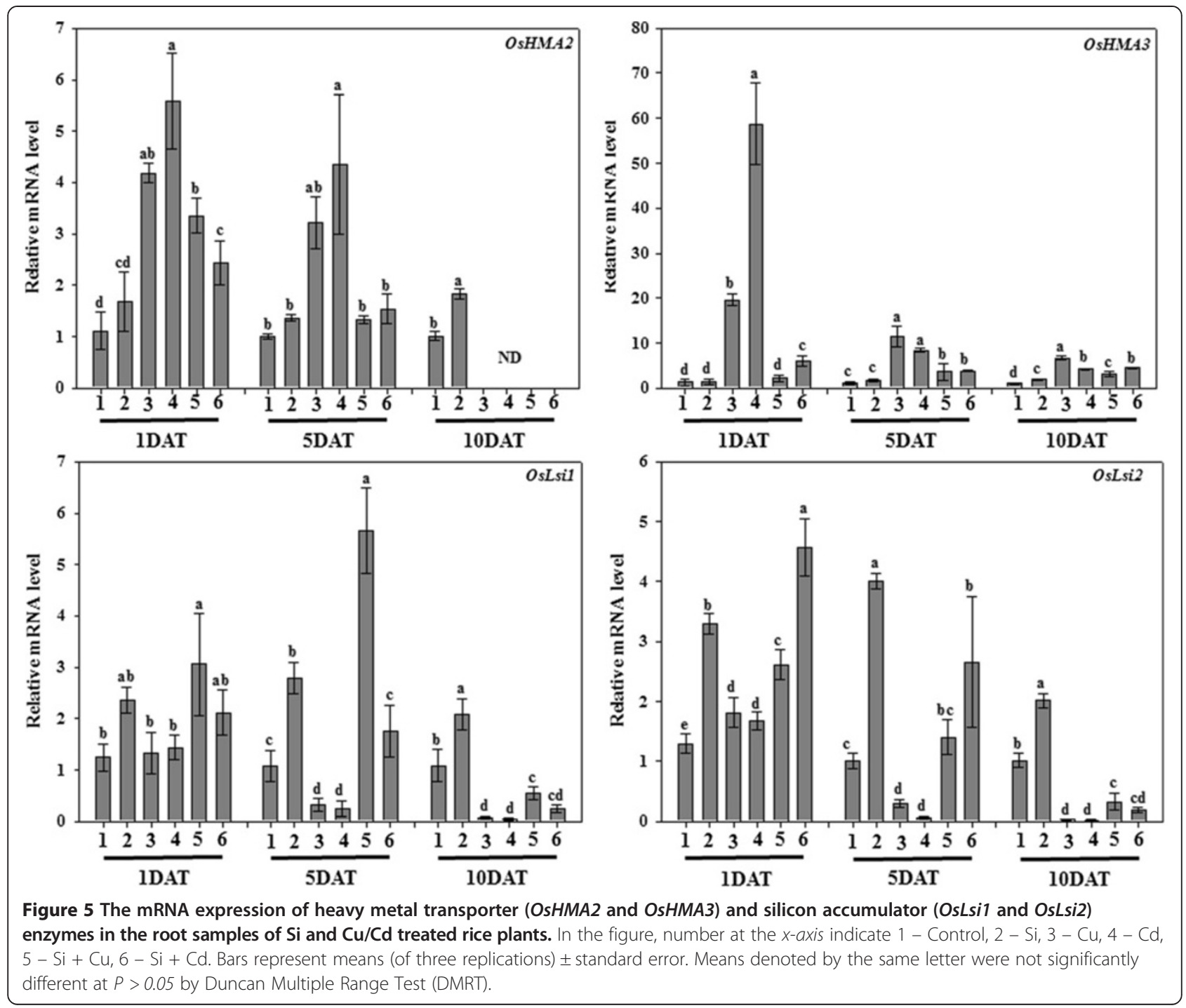

via the production of small oxygenated compounds such as MDA, signal and absorb ROS generated in these organelles. This proposed route for the elimination of ROS would be hemi-metabolic because it is initiated by nonenzymatic fatty acid fragmentation [54].

Alpha-linolenic acid, on the other hand, serves as a precursor of JA, a potent lipid molecule essential for signaling defenses during stress [30]. JA can act synergistically or antagonistically with other hormones, like salicylic acid (SA). SA plays a key role in regulating physiological processes, such as plant resistance to biotic and abiotic stresses [55-57], protection from ROS through antioxidant production, induction of gene expression, and absorption and distribution of elements under heavy metal stress conditions [57-59]. Higher levels of SA suggest an increased mitigation of ROS during metal stress. Interestingly, we found that $\mathrm{Si}$ treatment significantly lowers SA modulation during metal stress. While there was also a significant reduction of JA in the Si-treated plants under metalinduced stress, this is opposite to the effects we observed for $\mathrm{Si}$ on lipid peroxidation and fatty acid saturation. The release of $\alpha$-linolenic acid from plant membrane lipids by stress-activated lipases is thought to provide a substrate for lipoxygenase and the subsequent synthesis of JA [54]. Because the Si-treated plants were less affected by metal stress, perhaps the rice plant is able to consume less $\alpha$ linolenic acid for synthesizing JA. However, these dynamics are still unclear and extensive studies on $\mathrm{Si}$ and JA modulation during stress periods are required.

Abscisic acid (ABA), on the other hand, was significantly lower in Si-treated plants at 1-DAT and 5-DAT, but then increased at 10-DAT in the $\mathrm{Si}+$ metal-treated plants compared to the metal-treated plants. ABA plays an important role during many phases of the plant life cycle, including seed development and dormancy, and plant responses to various environmental stresses $[20,60]$. 
Some studies have reported that ABA content increases in plants exposed to $\mathrm{Cu}$ and $\mathrm{Cd}$ pollution [61], resulting in reduced stomatal conductance and hence, affecting photosynthesis and chlorophyll synthesis. These effects were ameliorated with $\mathrm{Si}$ treatment during metal stress and thus less ABA was formed. In our results, the ABA level was significantly reduced with $\mathrm{Si}$ treatment. ABA has an antagonistic behavior with JA/SA biosynthesis during $\mathrm{Si}$ treatment, suggesting an active role of ABA during $\mathrm{Si}$ and stress application. This is further confirmed by gene expression profile indicating salinity stress and ABA biosynthesis (unpublished data).

Our results also showed that OsLsi expressions were significantly higher in Si-treated plants at 1, 5, and 10DAT during $\mathrm{Cd} / \mathrm{Cu}$ stress, while in the non-Si-treated plant these were not expressed or expressed at low levels. The results suggest an active accumulation of $\mathrm{Si}$ via the roots, permitting its efficient deposition in the roots and shoots (data not shown). OsLsi2 is mainly expressed in the root parts at the plasma membrane [31]. Si deposition in the roots provides additional strength to the root structure for counteracting the intruding toxic metal ions, revealed in our micrographs after $\mathrm{Cd} / \mathrm{Cu}$ stress. Large amounts of $\mathrm{Si}$ aggregate in the exodermis and endodermis [62] and after 1 and 5-DAT, we observed less damage to the exodermis and endodermis regions of the roots compared to the non-Si plants during $\mathrm{Cd} / \mathrm{Cu}$ stress. Our results suggest a higher accumulation of $\mathrm{Si}$ in the roots reduced the influx of heavy metal. Thus, heavy metal transport was reduced in the $\mathrm{Si}$ treated plants compared to the non-Si plants. Similar results were revealed in the expression analysis of OsHMA2 and OsHMA3. The results also showed that during $\mathrm{Cu} / \mathrm{Cd}$ stress, the OsLsi genes were not activated vigorously compared to OsHMA3. However, after Si application in combination with the $\mathrm{Cu} / \mathrm{Cd}$ treatments, both OsHMA3 and OsLsi genes activated significantly to counteract the negative impacts of the metal stress. This further evidence supports our results of increase $\mathrm{Si}$ accumulation and amelioration of the plant growth attributes. This synergistic activation of OsHMA3 and OsLsi genes also showed that during metal stress, the root morphology was less disturbed compared to sole application of $\mathrm{Cu} / \mathrm{Cd}$. In conclusion, the findings of our study suggest a protective mechanism of Si during heavy metal stress. These results suggest that the application of $\mathrm{Si}$ may be an effective method for controlling $\mathrm{Cd} / \mathrm{Cu}$ transfer from contaminated paddy soil into the food chain.

\section{Methods}

\section{Plant material, Si and heavy metal application}

Rice Seeds (Oryza sativa L. cv Dongjinbeyo) were procured from the National Institute of Crop Science, Rural
Development Administration, Republic of Korea. Seeds were surface sterilized with $5 \%$ sodium hypochlorite for $15 \mathrm{~min}$ and thoroughly washed with autoclaved double distilled water. The rice seeds were grown on autoclaved sand medium for seven days to obtain equal length seedlings. Rice seedlings were then transplanted to hydroponic media and further grown till twenty-one days in growth chamber. The growth chamber (KGC-175 VH, KOENCON) conditions were programmed for a 14-hour light $\left(08: 00 \sim 22: 00 ; 30^{\circ} \mathrm{C}\right.$; relative humidity $\left.70 \%\right)$ and 10 hour dark $\left(22: 00 \sim 08: 00,25^{\circ} \mathrm{C}\right.$; relative humidity $\left.70 \%\right)$ cycle. Yoshida solution [63] was used as a growth medium for the rice seedlings in plastic pots $(25 \times 20 \times$ $20 \mathrm{~cm}$ ). Treatments were arranged factorially in a randomized experimental design with 27 plants per treatment. The treatments included (i) control (growth medium), (ii) sole $\mathrm{Si}$, (iii) cadmium $(\mathrm{Cd}) / \operatorname{copper}(\mathrm{Cu})$ and (iv) $\mathrm{Si}$ with $\mathrm{Cd} / \mathrm{Cu}$.

The twenty-one-day-old rice plants were treated with $\mathrm{Si}\left(\mathrm{Na}_{2} \mathrm{SiO}_{3} ; 1.0 \mathrm{mM}\right)$. The $\mathrm{pH}(5.1 \pm 0.1)$ of the rice growth medium was maintained by adding $\mathrm{HCl}$ to inhibit the polymerization of the silicates [64]. An equivalent amount of $\mathrm{Na}$ (as $\mathrm{NaCl}$ ) was also added to the zero Si-treated plants to compensate for the $\mathrm{Na}$ content of $1.0 \mathrm{mM}$ in the Si-treated plants. Heavy metal stress was applied to the root zone of the rice plants by adding $100 \mu \mathrm{M}$ cadmium $\left(\mathrm{CdCl}_{2}\right) /$ copper $\left(\mathrm{CuSO}_{4}\right)$. The metal stress was applied periodically for 1,5 , or 10 days. Each treatment was repeated in triplicate.

Rice plants were harvested after stress treatments, immediately frozen in liquid nitrogen, and shifted to $-80^{\circ} \mathrm{C}$. Prior to biochemical and hormonal analysis, plant samples were freeze-dried using a Virtis Freeze Dryer (Gardiner, NY, USA) for 4-7 days while for other experiments (such as mRNA expression analysis) fresh plant samples were used. The fresh shoot and root length were recorded after the treatment period. The chlorophyll contents were measured through a chlorophyll meter (SPAD-502 Minolta, Japan).

\section{Determination of the $\mathrm{Cd}, \mathrm{Cu}$, and Si concentration in rice roots}

After 1, 5, and 10 days, the $\mathrm{Cd}$ and $\mathrm{Cu}$-treated rice plant roots (with or without $\mathrm{Si}$ application) were thoroughly washed with double distilled water. The roots were then soaked in $0.5 \mathrm{M} \mathrm{HCl}$ for $20 \mathrm{~s}$, rinsed with double distilled water [65], and dried for 72 hours in an oven at $80^{\circ} \mathrm{C}$. Rice root samples were weighted and ground to a fine powder, and then digested in $5 \mathrm{ml}$ of a tertiary mixture of $\mathrm{HNO}_{3}$ : $\mathrm{H}_{2} \mathrm{SO}_{4}: \mathrm{HClO}_{4}(10: 1: 4(\mathrm{v} / \mathrm{v} / \mathrm{v}))$. The contents of $\mathrm{Cd}$ and $\mathrm{Cu}$ in the rice roots were determined with inductively coupled plasma (ICP) (Optima 7900DV, Perkin-Elmer, USA). 


\section{Microscopic analysis}

Rice seedlings' roots were fixed at $4^{\circ} \mathrm{C}$ in Karnovsky's fixative ( $2 \%$ glutaraldehyde, $1 \%$ paraformaldehyde, in $0.05 \mathrm{M}$ sodium cacodylate, $\mathrm{pH}$ 7.2). Samples were thoroughly washed two times in $0.05 \mathrm{M}$ sodium cacodylate buffer. The specimens were then dehydrated through a gradient ethanol series (30-50-70-80-90\%-absolute ethanol, 15 min each), and cleared in propylene oxide. Finally, the specimens were embedded in Spurr's epoxy resin. The resin was polymerized in a dry oven at $70^{\circ} \mathrm{C}$ for 8 hours. Semi-thin sections were obtained using an ultra-microtome (MT-7000, RMC, USA) and then the sections were observed by differential interference contrast microscopy (Olympus, Japan).

\section{Abscisic acid extraction and quantification}

The endogenous ABA content was quantified from the frozen samples by following the protocols of Qi et al. [66] and Kamboj et al. [67]. Aerial parts of the plant samples were extracted with $30 \mathrm{ml}$ of extraction solution containing 95\% isopropanol, 5\% glacial acetic acid, and $20 \mathrm{ng}$ of $[( \pm)-3,5,5,7,7,7-\mathrm{d} 6]-\mathrm{ABA}$. The filtrate was concentrated by a rotary evaporator. The residue was dissolved in $4 \mathrm{ml}$ of $1 \mathrm{~N}$ sodium hydroxide solution, and then washed three times with $3 \mathrm{ml}$ of methylene chloride to remove lipophilic materials. The aqueous phase, brought to approximately a pH of 3.5 with $6 \mathrm{~N}$ hydrochloric acid was partitioned three times into ethyl acetate (EtOAc). EtOAc extracts were then combined and evaporated. The dried residue was dissolved in phosphate buffer ( $\mathrm{pH} 8.0$ ) and then run through a polyvinylpolypyrrolidone (PVPP) column. The phosphate buffer was adjusted to $\mathrm{pH} 3.5$ with $6 \mathrm{~N} \mathrm{HCl}$ and partitioned three times into EtOAc. EtOAc extracts were combined again and evaporated. The residue was dissolved in dichloromethane $\left(\mathrm{CH}_{2} \mathrm{Cl}_{2}\right)$, and passed through a silica cartridge (Sep-Pak; Water Associates, Milford, Massachusetts, USA) pre-washed with $10 \mathrm{ml}$ of diethyl ether: methanol $(3: 2, \mathrm{v} / \mathrm{v})$ and $10 \mathrm{ml}$ of dichloromethane. ABA was recovered from the cartridge by elution with $10 \mathrm{ml}$ of diethyl ether $\left(\mathrm{CH}_{3}-\mathrm{CH}_{2}\right)_{2} \mathrm{O}$ : methanol $(\mathrm{MeOH})(3: 2, \mathrm{v} / \mathrm{v})$. The extracts were dried and methylated by adding diazomethane for GC/MS-SIM (6890 N network GC system, and the 5973 network mass-selective detector; Agilent Technologies, Palo Alto, CA, USA) analysis. For quantification, the Lab-Base (ThermoQuset, Manchester, UK) data system software was used to monitor responses to ions with an m/e of 162 and 190 for Me-ABA and 166 and 194 for $\mathrm{Me}-\left[{ }^{2} \mathrm{H}_{6}\right]-\mathrm{ABA}$.

\section{Jasmonic acid extraction and quantification}

The endogenous JA level was quantified according to the protocol of McCloud and Baldwin [68]. The lyophilized aerial tissues parts were ground to a fine powder with a mortar and pestle. The powder $(0.1 \mathrm{~g})$ was suspended in a solution of acetone and $50 \mathrm{mM}$ citric acid (70:30, v/v) and $\left[9,10-{ }^{2} \mathrm{H}_{2}\right]-9,10$-dihydro-JA (20 ng) was added as an internal standard. The extracts were allowed to evaporate overnight at room temperature to avoid the loss of volatile fatty acids. The resulting aqueous solutions were then filtered and extracted three times, each time with $10 \mathrm{~mL}$ of diethyl ether. The pooled extracts were then loaded on a solid phase extraction cartridge (500 mg of sorbent, aminopropyl). After loading, the cartridges were washed with $7.0 \mathrm{~mL}$ of trichloromethane and 2-propanol $(2: 1, \mathrm{v} / \mathrm{v})$. The bound JA and the pertinent standard were eluted with $10 \mathrm{~mL}$ of diethyl ether and acetic acid (98:2, v/v). After evaporation of the solvents and esterification of the residue with excess diazomethane, the sample was adjusted to $50 \mu \mathrm{L}$ with dichloromethane. The extracts were then analyzed by GCMS (6890 N network GC system and the 5973 network mass selective detector; Agilent Technologies, Palo Alto, CA, USA). To enhance the sensitivity of the method, spectra were recorded in the selected-ion mode. For JA determination, the fragment ion was monitored at $\mathrm{m} / \mathrm{z}=$ $83 \mathrm{amu}$ corresponding to the base peaks of JA and [9, 10${ }^{2} \mathrm{H}_{2}$ ]-9, 10-dihydro-JA. The amounts of endogenous JA were calculated from the peak areas of JA compared to the corresponding standards. The experiment was repeated three times.

\section{Free salicylic acid extraction and quantification}

Free SA was extracted and quantified as described by Enyedi et al. [69] and Seskar et al. [70]. Freeze-dried aerial tissue samples were ground to powder form, and 0.1 g was sequentially extracted with $90 \%$ and $100 \%$ methanol by centrifuging at $10,000 \times \mathrm{g}$. The combined methanol extracts were vacuum-dried. The dry pellets were resuspended in $2.5 \mathrm{ml}$ of $5 \%$ trichloroacetic acid, and the supernatant was partitioned with ethyl acetate/ cyclopentane/isopropanol (49.5:49.5:1, v/v). The top organic layer, containing free SA, was transferred to a $4 \mathrm{ml}$ vial and dried with nitrogen gas. The dry SA was again suspended in $1 \mathrm{~mL}$ of $70 \%$ methanol. High-performance liquid chromatography (HPLC) analyses were carried out on a Shimadzu fluorescence detector (Shimadzu RF-10AXL, excitation and emission detected at 305 and $365 \mathrm{~nm}$, respectively) fitted with a C18 reverse-phase HPLC column (HP hypersil ODS; particle size, $5 \mu \mathrm{m}$; pore size, 120 - $\AA$ water; Additional file 1: Table S1). The flow rate was $1.0 \mathrm{ml} / \mathrm{min}$. The $\mathrm{SA}$ analyses were repeated three times.

\section{Determination of lipid peroxidation activity}

The extent of lipid peroxidation was determined by the method of Ohkawa et al. [71]. For this assay, $0.2 \mathrm{ml}$ of $8.1 \%$ sodium dodecyl sulphate, $1.5 \mathrm{ml}$ of $20 \%$ acetic acid 
(pH 3.5), and $1.5 \mathrm{ml}$ of $0.81 \%$ thiobarbituric acid aqueous solution were added in succession in a reaction tube. Then $0.2 \mathrm{ml}$ of root tissue homogenate extracted was added to $10 \mathrm{mM}$ phosphate buffer ( $\mathrm{pH}$ 7.0). The mixture was then heated in boiling water for $60 \mathrm{~min}$. After cooling to room temperature, a $5 \mathrm{ml}$ butanol/pyridine $(15: 1 \mathrm{v} / \mathrm{v})$ solution was added. The upper organic layer was separated, and the optical density of the resulting pink color was recorded at $532 \mathrm{~nm}$ using a spectrophotometer. Tetramethoxypropane was used as an external standard. The level of lipid peroxides was expressed as micromoles of malondialdehyde (MDA) formed/gram tissue weight. The experiments were repeated three times.

\section{Fatty acid analysis}

The root tissues of rice plants $(1 \mathrm{~g})$ were treated with $10 \mathrm{ml}$ of hexane. The samples were then placed in a shaking incubator $(150 \mathrm{rpm})$ at $50^{\circ} \mathrm{C}$ for 2 days. The supernatant was separated by centrifugation $(1,200 \times \mathrm{g}$ at $25^{\circ} \mathrm{C}$ ) followed by transfer into new tubes. Hexane was evaporated by passing air in an evaporating unit. The extracted material from each sample was placed in a screw-capped vial, and $5 \mathrm{ml}$ of methylation solution $\left(\mathrm{H}_{2} \mathrm{SO}_{4} /\right.$ methanol/toluene 01:20:10 ml) were added. The sealed vial was heated in a water bath $\left(100^{\circ} \mathrm{C}\right)$ for $60 \mathrm{~min}$ and allowed to cool to room temperature. Then $5 \mathrm{ml}$ of water was added and shaken. The mixture was separated into two layers, and the upper layer was taken by Pasteur pipette and dried using anhydrous sodium sulphate for $5 \mathrm{~min}$. One microliter of sample was directly injected into the GC using an automatic sampler (Agilent 7683B). GC-MS analysis was carried out on the Agilent Model 7890A series (Agilent, Dover, DE, USA) equipped with an Agilent 5975C MS detector and an Agilent 7683 autosampler, and a MS ChemStation Agilent v. A.03.00 was used. The GC-MS was equipped with a DB-5MS capillary column $(30 \mathrm{~m} \times 0.25 \mathrm{~mm}$ i.d. $\times$ $0.25 \mu \mathrm{m}$ film thickness; J\&W Scientific-Agilent, Folsom, CA, USA), while helium was used as a carrier gas with a flow rate of $0.6 \mathrm{ml} / \mathrm{min}$ in split mode (1:50). The injector temperature and detector temperature were 120 and $200^{\circ} \mathrm{C}$, respectively. The column temperature was programmed from 50 to $200^{\circ} \mathrm{C}$ at $10^{\circ} \mathrm{C} / \mathrm{min}$ and then finally held at $200^{\circ} \mathrm{C}$ for $5 \mathrm{~min}$. The mass conditions were as follows: ionization voltage, $70 \mathrm{eV}$; scan rate, $1.6 \mathrm{scan} / \mathrm{s}$; mass range, 30-450; and ion source temperature, $180^{\circ} \mathrm{C}$. The components were identified based on their relative retention time and mass spectra compared with standards, Wiley7N, NIST library data of the GC-MS system, and data from the literature. The values of the fatty acids (palmitic acid, stearic acid, oleic acid, linoleic acid, and linolenic acid) were calculated in milligram/ gram $\times 10^{-1}$.

\section{RNA extraction and RT-PCR analysis}

The root samples of rice plants treated with heavy metals and $\mathrm{Si}$ were harvested in liquid nitrogen (after 1, 5 , or 10 days) and immediately shifted to $-80^{\circ} \mathrm{C}$. Total RNA was extracted from rice plant samples using an RNeasy plant extraction minikit (Qiagen) according to the manufacturer's instructions. First-strand cDNA was synthesized from $1 \mu \mathrm{g}$ of total RNA using an oligo (dT) 18 primer and the SuperScript first strand synthesis system was used for the reverse transcriptase polymerase chain reaction (RT-PCR). RT-PCR was performed in a $50 \mu \mathrm{l}$ solution containing a $1 \mu \mathrm{l}$ aliquot of the cDNA reaction, $0.2 \mu \mathrm{M}$ of gene-specific primers, $10 \mathrm{mM}$ dNTPs, and 1 unit of rTaq DNA polymerase. PCR conditions included 30 cycles of denaturation at $95^{\circ} \mathrm{C}$ for $45 \mathrm{~s}$, annealing at $53^{\circ} \mathrm{C}$ for $45 \mathrm{~s}$ and extension at $72^{\circ} \mathrm{C}$ for $90 \mathrm{~s}$. PCR products were barely visible when the agarose gels were stained with ethidium bromide. These products were separated by electrophoresis on a 1.0\% agarose gel, blotted onto a nylon membrane, and hybridized with a ${ }^{32} \mathrm{P}$-labeled probe specific to each gene that was generated from the non-conserved 3' end regions. The RTPCR analyses were performed according to the method of Lee et al. [14], Ma et al. [31,35] and Nocito et al. [34] (Additional file 2: Table S2). OsAct1 was used as a standard gene.

\section{Statistical analysis}

The data was statistically analyzed for standard deviation and error using Sigma Plot software (2004). The mean values were compared using Duncan's multiple range tests at $P<0.05$ (ANOVA SAS release 9.1; SAS, Cary, NC, USA).

\section{Additional files}

Additional file 1: Table S1. HPLC conditions used for salicylic acid analysis.

Additional file 2: Table S2. List of primers used for RT-PCR analysis.

\begin{abstract}
Abbreviations
Cd: Cadmium; Cu: Copper; HMAS: Heavy metal ATPase; LCTs: Low-affinity cation transporter; IRTs: Iron regulated transporter; ROS: Reactive oxygen species; MDA: Malondialdehyde; JA: Jasmonic acid; SA: Salicylic acid ABA: Abscisic acid; Si: Silicon; OsLsi: Oryza sativa low silicon; EX: Exodermis; EP: Epidermis; EN: Endodermis; DAT: Day after treatment; ICP: Inductively coupled plasma.
\end{abstract}

Competing interests

The authors declare that they have no competing interests.

\section{Authors' contributions}

YHK and ALK designed and performed the experiments. DHK, SYL and HYJ performed the microscopy analysis for the work. KMK, MW, JGK and JHS performed the molecular analysis. YHK, ALK and IJL wrote the manuscript. All authors read and approved the final manuscript. 


\section{Acknowledgements}

The present research work was funded by the Eco-Innovation Project, Korean Governments R \& D program on Environmental Technology and Development, Republic of Korea.

\begin{abstract}
Author details
${ }^{1}$ School of Applied Biosciences, College of Agriculture and Life Science, Kyungpook National University, Daegu 702-701, Republic of Korea. 2Department of Biological Science \& Chemistry, University of Nizwa, Nizwa 616, Oman. ${ }^{3}$ Department of Life Sciences and Biotechnology, Kyungpook National University, Daegu 702-701, Republic of Korea.
\end{abstract}

Received: 13 February 2013 Accepted: 7 January 2014

Published: 9 January 2014

\section{References}

1. Lin CC, Chen LM, Liu ZH: Rapid effect of copper on lignin biosynthesis in soybean roots. Plant Sci 2005, 168:855-861.

2. Maksymiec W: Signalling responses in plants to heavy metal stress. Acta Physiol Plant 2007, 29:177-187.

3. Molas J: Changes of chloroplast ultrastructure and total chlorophyll concentration in cabbage leaves caused by excess of organic $\mathrm{Ni}(\mathrm{II})$ complexes. Environ Exp Bot 2002, 47:115-126.

4. Shah K, Kumar RG, Verma S, Dubey RS: Effect of cadmium on lipid peroxidation, superoxide anion generation and activities of antioxidant enzymes in growing rice seedlings. Plant Sci 2001, 161:1135-1144.

5. Liu JG, Liang JS, Li KQ, Zhang ZJ, Yu BY, Lu XL, Yang JC, Zhu QS: Correlations between cadmium and mineral nutrients in absorption and accumulation in various genotypes of rice under cadmium stress. Chemosphere 2003, 52:1467-1473.

6. Kikuchi T, Okazaki M, Toyota K, Motobayashi T, Kato M: The input-output balance of cadmium in a paddy field of Tokyo. Chemosphere 2007, 67:920-927.

7. Takahashi R, Ishimaru Y, Senoura T, Shimo H, Ishikawa S, Arao T, Nakanishi H, Nishizawa NK: The OsNRAMP1 iron transporter is involved in Cd accumulation in rice. J Exp Bot 2011, 62:4843-4850.

8. Patra M, Bhowmik N, Bandopadhyay B, Sharma A: Comparison of mercury, lead and arsenic with respect to genotoxic effects on plant systems and the development of genetic tolerance. Environ Exp Bot 2004, 52:199-223.

9. Tudoreanu L, Phillips CJC: Modeling cadmium uptake and accumulation in plants. Adv Agron 2004, 84:121-157.

10. Pál M, Horváth E, Janda T, Páldi E, Gabriella S: Physiological changes and defense mechanisms induced by cadmium stress in maize. J Plant Nutr Soil Sci 2007, 169:239-246.

11. Uraguchi S, Kamiya T, Sakamoto T, Kasai K, Sato Y, Nagamura Y, Yoshida A, Kyozuka J, Ishikawa S, Fujiwara T: Low-affinity cation transporter (OsLCT1) regulates cadmium transport into rice grains. Proc Natl Acad Sci USA 2011 108:20959-20964.

12. Satoh-Nagasawa N, Mori M, Nakazawa N, Kawamoto T, Nagato Y, Sakurai K, Takahashi H, Watanabe A, Akagi H: Mutations in rice (Oryza sativa) heavy metal ATPase2 (OsHMA2) restrict the translocation of zinc and cadmium. Plant Cell Physiol 2012, 53:213-224.

13. Kuhlbrandt W: Biology, structure and mechanism of P-type ATPases. Nat Rev Mol Cell Biol 2004, 5:282-295.

14. Lee SC, Kim YY, Lee YS, An GH: Rice $P_{1 B}$-Type heavy-metal ATPase, OsHMA9, is a metal efflux protein. Plant Physiol 2007, 145:831-842.

15. Verret F, Gravot A, Auroy P, Leonahardt N, David P, Nussaume L, Vavasseur A, Richaud P: Overexpression of AtHMA4 enhances root-to-shoot translocation of zinc and cadmium and plant metal tolerance. FEBS Lett 2004, 576:306-312.

16. Courbot M, Willems G, Motte P, Arvidsson S, Roosens N, Saumitou-Laprade $P$, Verbruggen $\mathrm{N}$ : A major quantitative trait locus for cadmium tolerance in Arabidopsis halleri colocalizes with HMA4, a gene encoding a heavy metal ATPase. Plant Physiol 2007, 144:1052-1065.

17. Kim YY, Choi H, Segami S, Cho HT, Martinoia E, Maeshima M, Lee Y. AtHMA1 contributes to the detoxification of excess $\mathrm{Zn}(\mathrm{II})$ in Arabidopsis. Plant J 2009, 58:737-753

18. Wong CKE, Cobbett CS: HMA P-type ATPases are the major mechanism for root-to-shoot Cd translocation in Arabidopsis thaliana. New Phytol 2009, 181:71-78.
19. Esterbauer $\mathrm{H}$, Cheeseman $\mathrm{KH}$ : Determination of aldehydic lipidperoxidation products: malonaldehyde and 4-hydroxynonenal. Methods Enzymol 1990, 186:407-421.

20. Lee SC, Luan S: ABA signal transduction at the crossroad of biotic and abiotic stress responses. Plant Cell Environ 2012, 35:53-60.

21. Epstein E: The anomaly of silicon in plant biology. Proc Natl Acad Sci USA 1994, 91:11-17.

22. Yamaji N, Ma JF: Further characterization of a rice silicon efflux transporter, Lsi2. Soil Sci Plant Nutr 2011, 57:259-264.

23. Epstein E: Silicon. Annu Rev Plant Physiol Plant Mol Biol 1999, 50:641-664.

24. Savant NK, Korndorfer GH, Datnoff LE, Snyder GH: Silicon nutrition and sugarcane production: a review. J Plant Nutr 1999, 22:1853-1903.

25. Ma JF, Miyak Y, Takahashi E: Silicon as a beneficial element for crop plants. In Silicon in agriculture. Edited by Datonoff LF, Snyder GH, Korndorfer GH. Amsterdam: Elsevier Science Publishers; 2001:17-39.

26. Liang YC, Chen Q, Liu Q, Zhang WH, Ding RX: Exogenous silicon (Si) increases antioxidant enzyme activity and reduces lipid peroxidation in roots of salt-stressed barley (Hordeum vulgare L.). J Plant Physiol 2003, 160:1157-1164.

27. Liang YC, Ding RX: Influence of silicon on microdistribution of mineral ions in roots of salt-stressed barley as associated with salt tolerance in plants. Sci China (Series C) 2002, 45:298-308

28. Hamayun M, Sohn EY, Khan SA, Shinwari ZK, Khan AL, Lee IJ: Silicon alleviates the adverse effects of salinity and drought stress on growth and endogenous plant growth hormones of soybean (Glycine max L.). Pak J Bot 2010, 42:1713-1722

29. Chen W, Yao X, Cai K, Chen J: Silicon alleviates drought stress of rice plants by improving plant water status, photosynthesis and mineral nutrient absorption. Biol Trace Elem Res 2011, 142:67-76.

30. Kim YH, Khan AL, Hamayun M, Kang SM, Beom YJ, Lee IJ: Influence of short-term silicon application on endogenous physiohormonal levels of Oryza sativa L. under wounding stress. Biol Trace Elem Res 2011 144:1175-1185.

31. Ma JF, Yamaji N, Mitani N, Tamai K, Konishi S, Fujiwara T, Katsuhara M, Yano M: An efflux transporter of silicon in rice. Nature 2007, 448:209-212.

32. Hussain D, Haydon MJ, Wang Y, Wong E, Sherson SM, Young J, Camakaris J, Harper JF, Cobbett CS: P-type ATPase heavy metal transporters with roles in essential zinc homeostasis in Arabidopsis. Plant Cell 2004, 16:1327-1339.

33. Andrés-Colás N, Sancenón V, Rodríguez-Navarro S, Mayo S, Thiele DJ, Ecker JR, Puig S, Peñarrubia L: The Arabidopsis heavy metal P-type ATPase HMA5 interacts with metallochaperones and functions in copper detoxification of roots. Plant J 2006, 45:225-236.

34. Nocito FF, Lancilli C, Dendena B, Lucchini G, Sacchi GA: Cadmium retention in rice roots is influenced by cadmium availability, chelation and translocation. Plant Cell Environ 2011, 34:994-1008.

35. Ma JF, Yamaji N, Mitani N, Xu XY, Su YH, McGrath SP, Zhao FJ: Transporters of arsenite in rice and their role in arsenic accumulation in rice grain. Proc Natl Acad Sci USA 2008, 105:9931-9935.

36. Fujimaki S, Suzui N, Ishioka NS, Kawachi N, Ito S, Chino M, Nakamura S: Tracing cadmium from culture to spikelet: noninvasive imaging and quantitative characterization of absorption, transport, and accumulation of cadmium in an intact rice plant. Plant Physiol 2010, 152:1796-1806.

37. Shimo H, Ishimaru Y, An G, Yamakawa T, Nakanishi H, Nishizawa NK: Low cadmium (LCD), a novel gene related to cadmium tolerance and accumulation in rice. J Exp Bot 2011, 62:5727-5734.

38. Chien HF, Kao CH: Accumulation of ammonium in rice leaves in response to excess cadmium. Plant Sci 2000, 156:111-115.

39. McGrath SP, Zhao FJ, Lombi E: Plant and rhizosphere processes involved in phytoremediation of metal contaminated soil. Plant Soil 2001 232:207-214.

40. Sharma SS, Dietz KJ: The relationship between metal toxicity and cellular redox imbalance. Trends Plant Sci 2009, 14:43-50.

41. Abdel-Ghany SE, Müller-Moulé P, Niyogi KK, Pilon M, Shikanai T: Two P-type ATPases are required for copper delivery in Arabidopsis thaliana chloroplasts. Plant Cell 2005, 17:1233-1251.

42. Sudo E, Itouga M, Yoshida-Hatanaka K, Ono Y, Sakakibara H: Gene expression and sensitivity in response to copper stress in rice leaves. J Exp Bot 2008, 59:3465-3474

43. Langer I, Krpata D, Fitz WJ, Wenzel WW, Schweiger PF: Zinc accumulation potential and toxicity threshold determined for a metal-accumulating 
Populus canescens clone in a dose-response study. Environ Pollut 2009, 157:2871-2877.

44. Liu C, Li F, Luo C, Liu X, Wang S, Liu T, Li X: Foliar application of two silica sols reduced cadmium accumulation in rice grains. J Hazardous Mat 2009, 161:1466-1472.

45. Baryla A, Carrier P, Franck F, Coulomb C, Sahut C, Havaux M: Leaf chlorosis in oilseed rape plants (Brassica napus) grown on cadmium-polluted soil: causes and consequences for photosynthesis and growth. Planta 2001, 212:696-709.

46. Chen HM, Zheng CR, Tu C, Shen ZG: Chemical methods and phytoremediation of soil contaminated with heavy metals. Chemosphere 2000, 41:229-234.

47. Shi XH, Zhang $\mathrm{CH}$, Wang $\mathrm{H}$, Zhang FS: Effect of Si on the distribution of Cd in rice seedlings. Plant Soil 2005, 272:53-60.

48. da Cunha KPV, do Nascimento CWA: Silicon effects on metal tolerance and structural changes in maize (Zea mays L.) grown on a cadmium and zinc enriched soil. Water Air Soil Poll 2009, 197:323-330.

49. Landberg L, Greger M: Differences in oxidative stress in heavy metal resistant and sensitive clones of Salix viminalis. J Plant Physiol 2002, 159:69-75.

50. Morelli E, Scarano G: Copper-induced changes of non-protein thiols and antioxidant enzymes in the marine microalga Phaeodactylum tricornutum. Plant Sci 2004, 167:289-296.

51. Zhang $H$, Xia $Y$, Wang G, Shen Z: Excess copper induces accumulation of hydrogen peroxide and increases lipid peroxidation and total activity of copper-zinc superoxide dismutase in roots of Elsholtzia haichowensis. Planta 2008, 227:465-475.

52. Davey MW, Stals E, Panis B, Keulemans J, Swennen RL: High-throughput determination of malondialdehyde in plant tissues. Anal Biochem 2005, 347:201-207.

53. Weber H, Chételat A, Reymond P, Farmer EE: Selective and powerful stress gene expression in Arabidopsis in response to malondialdehyde. Plant J 2004, 37:877-889

54. Upchurch RG: Fatty acid unsaturation, mobilization, and regulation in the response of plants to stress. Biotechnol Lett 2008, 30:967-977.

55. Molina A, Bueno P, Marín MC, Rodríguez-Rosales MP, Belver A, Venema K, Donaire JP: Involvement of endogenous salicylic acid content, lipoxygenase and antioxidant enzyme activities in the response of tomato cell suspension cultures to $\mathrm{NaCl}$. New Phytol 2002, 156:409-415.

56. He Y, Liu Y, Cao W, Hua M, Xu B, Huang B: Effects of salicylic acid on heat tolerance associated with antioxidant metabolism in Kentucky bluegrass. Crop Sci 2005, 45:988-995.

57. Shi Q, Zhu Z: Effects of exogenous salicylic acid on manganese toxicity, element contents and antioxidative system in cucumber. Environ Exp Bot 2008, 63:317-326

58. Metwally A, Finkemeier I, Georgi M, Dietz KJ: Salicylic acid alleviates the cadmium toxicity in barley seedlings. Plant Physiol 2003, 132:272-281.

59. Wang YS, Wang J, Yang ZM, Wang QY, Li B, Li SQ, Lu YP, Wang SH, Sun X: Salicylic acid modulates aluminum-induced oxidative stress in roots of Cassia tora. Acta Bot Sin 2004, 46:819-828.

60. Hey SJ, Byrne E, Halford NG: The interface between metabolic and stress signaling. Ann Bot 2010, 105:197-203.

61. Monni S, Uhling C, Hansen E, Magel E: Ecophysiological responses of Empetrum nigrum to heavy metal pollution. Environ Poll 2001, 112:121-129.

62. Gong HJ, Randall DP, Flowers TJ: Silicon deposition in the root reduces sodium uptake in rice (Oryza sativa L.) seedlings by reducing bypass flow. Plant Cell Environ 2006, 29:1970-1979.

63. Yoshida S, Ohnishi Y, Kitagishi K: Role of silicon in rice nutrition. Soil Plant Food 1959, 5:127-133.

64. Brady AP, Brown AG, Huff H: The polymerization of aqueous potassium silicate solutions. J Colloid Sci 1953, 8(2):252-276.

65. Kaya C, Tuna AL, Sonmez O, Ince F, Higgs D: Mitigation effects of silicon on maize plants grown at high zinc. J Plant Nut 2009, 32:1788-1798.

66. Qi QG, Rose PA, Abrams GD, Taylor DC, Abrams SR, Cutler AJ: (?)-Abscisic acid etabolism, 3-ketoacylcoenzyme A synthase gene expression, and very-longchain monounsaturated fatty acid biosynthesis in Brassica napus embryos. Plant Physiol 1998, 117:979-987.

67. Kamboj JS, Browning G, Blake PS, Quinlan JD, Baker DA, Kamboj JS: GC-MS SIM analysis of abscisic acid and indole-3-acetic acid in shoot bark of apple root stocks. J Plant Growth Regul 1999, 28:21-27.
68. McCloud ES, Baldwin IT: Herbivory and caterpillar regurgitants amplify the wound-induced increases in jasmonic acid but not nicotine in Nicotiana sylvestris. Planta 1997, 203:430-435

69. Enyedi AJ, Yalpani N, Silverman P, Raskin I: Localization, conjugation, and function of salicylic acid in tobacco during the hypersensitive reaction to tobacco mosaic virus. Proc Natl Acad Sci USA 1992, 89:2480-2484.

70. Seskar M, Shulaev V, Raskin I: Endogenous methyl salicylate in pathogeninoculated tobacco plants. Plant Physiol 1998, 116:387-392

71. Ohkawa H, Ohishi N, Yagi K: Assay for lipid peroxides in animal tissues by thiobabituric acid reaction. Anal Biochem 1979, 95:358.

doi:10.1186/1471-2229-14-13

Cite this article as: Kim et al: Silicon mitigates heavy metal stress by regulating P-type heavy metal ATPases, Oryza sativa low silicon genes, and endogenous phytohormones. BMC Plant Biology 2014 14:13.

\section{Submit your next manuscript to BioMed Central and take full advantage of:}

- Convenient online submission

- Thorough peer review

- No space constraints or color figure charges

- Immediate publication on acceptance

- Inclusion in PubMed, CAS, Scopus and Google Scholar

- Research which is freely available for redistribution
C) BioMed Central 